\title{
TISSUE PROTEIN STUDIES IN NORMAL AND UNDERNOURISHED MALES: THE CHANGES IN TOTAL CIRCULATING PROTEIN AFTER AN INTRAVENOUS SALINE INFUSION AS AN INDEX OF PROTEIN STORES ${ }^{1}$
}

\author{
By JOHN E. HARROUN,² CHARLEY J. SMYTH, ${ }^{3}$ AND STANLEY LEVEY
}

(From the Departments of Medicine and Physiological Chemistry, Wayne University College of Medicine, Detroit, Michigan, and Wayne County General Hospital, Eloise, Michigan)

(Received for publication June 7, 1949)

In 1934 Whipple et al. (1) suggested that protein stores existed in body tissues and postulated that a "dynamic equilibrium" between plasma proteins and these tissue stores was an integral part of protein metabolism. This concept has gradually been accepted by most investigators in the field of nutrition (2-4). Shearburn in 1942 (5), following the lead of Calvin $(6,7)$, presented data obtained in normal and in hypoproteinemic dogs showing that the presence or absence of protein storcs could be demonstrated after an intravenous saline infusion. These fundamental observations in regard to tissue proteins are important in explaining the equilibrium state as set forth by Whipple and to our knowledge have not been included in any of the recent discussions on this subject.

At present, the clinical signs which suggest protein deficiency, except in extreme cases, are totally inadequate to give an exact evaluation of the state of nutrition of a given subject. Also, it is generally accepted that the serum protein concentration does not reflect the true nutritional state. Ravdin (8) has stated, "If the means to determine it were available, the first effect of protein undernutrition is a reduction in the amount of protein stores in the tissues of the body since every attempt is made to maintain the serum protein concentration at a nearly normal level."

Localio et al. (9) in an attempt accurately to evaluate protein reserves, determined the nitrogen

\footnotetext{
1 A preliminary report was presented before the American Institute of Nutrition in Detroit, April 1949. This study was supported in part by grants-in-aid from Merck and Company, Mead Johnson Company, and the Upjohn Company.

2 Present address: Watson Clinic, Brookings, South Dakota.

3 Present address: University of Colorado Medical Center, Denver, Colorado.
}

content of the rectus abdominis fascia, at the time of surgery, in patients suspected of having a protein deficiency and in patients who were considered to be in a state of normal nutrition. This method of evaluating tissue proteins is of no value before surgery and, in addition, is arduous and time consuming. Furthermore, one must assume that all tissues react in a manner similar to the rectus abdominis fascia. It has long been known that the amount of nitrogen excreted by animals or man, during a period on a protein deficient diet, decreases as the experiment is continued until a "minimal" level is reached. Allison (2) has stated: "The amount of nitrogen excreted when the animal is eating a protein-free diet is a measure of the magnitude of the protein stores of the body, being high when the labile cytoplasmic proteins are in abundance and being low when these stores are depleted." Boothby et al. (10) and Deuel et al. (11) did similar work in humans, using intravenous thyroxin to increase metabolism in an attempt to evaluate protein stores in man. Such a procedure is not practical for routine evaluation of the state of protein nutrition in clinical patients.

Realizing the need for a means of evaluating the status of protein nutrition in clinical patients, studies were undertaken to develop a method of quantitatively assaying the nutritional state of a patient with respect to proteins. This report presents the results of these observations; it provides a practical method for demonstrating the existence or absence of adequate tissue protein.

\section{METHODS}

The nine undernourished subjects in this study were chosen on the basis of the following criteria: a definite weight loss over a variable period up to six months preceding the study (estimated at 20 pounds or more in severe undernutrition); a history of inadequate food intake; 
signs of vitamin deficiencies (e.g., poor night vision, red tongue, cheilitis or peripheral neuritis) which in general would denote poor dietary habits. Some of these subjects had a low serum protein value which was accepted as evidence of poor intake or faulty utilization of protein; others had normal levels of total serum protein, but this was not considered necessarily to indicate good protein nutrition. A low serum albumin value, with or without a rise of globulin, was also accepted as evidence of poor protein intake or faulty utilization. The six normal subjects used in the study manifested none of the above signs and had had no recent illness.

In each of the normal subjects the plasma volume, total serum proteins and fractions (albumin and globulin) were performed before and again 30 minutes after the infusion of 1 liter of physiological saline. The infusion was given at a rate of approximately $20 \mathrm{ml}$. per minute. In one subject, J. Ca., these studies were conducted twice. In the undernourished subjects, these same determinations were made once in all instances and in four cases once or more following periods of refeeding as described below.

The plasma volume was determined using the dye $\mathrm{T}$ 1824 according to the method of Gibson and Evans (12) as modified for the photoelectric colorimeter (13). Dyedblood specimens were obtained without venostasis at intervals of $10,15,20$ and 25 or $10,13,16$ and 19 minutes following the injection of the dye. The same needle was used to withdraw all of the dyed-blood specimens; a 0.4 per cent solution of sodium citrate was used to keep the needle "open." To accomplish this a 2-ml. syringe containing $1 \mathrm{ml}$. of the citrate was attached to the needle and $1 / 2 \mathrm{ml}$. of citrate was injected slowly; to avoid dilution, $1 / 2 \mathrm{ml}$. of blood was withdrawn into the $2-\mathrm{ml}$. syringe and discarded just prior to withdrawing each sample to be analyzed. Each patient was thus subjected to a minimum of venipunctures, usually only three, during each complete study involving two plasma volume determinations.

The concentration of protein in the serum was estimated by nitrogen determination and converting nitrogen to prote. $n$ by multiplying by the factor 6.25 . Serum samples were subjected to $\mathrm{Kjeldahl}$ digestion using sulfuric acid and hydrogen peroxide; the ammonia formed was determined by means of Conway cells (14).

Fractionation of the serum proteins into album:n and globulin was accomplished by using the methanol precipitation procedure of Pillemer and Hutchinson (15). Albumin was determined by estimating the nitrogen in the methanol solution after removing the precipitated globulin; nitrogen was determined by the same method given above for serum proteins. The difference between total protein and albumin in the serum was considered to be globulin.

After the above procedure, four of the malnourished patients were encouraged to consume a high caloric and high protein diet. The amount consumed varied from between 3000 to 4500 calories per day. This diet provided from 2.0 to $4.5 \mathrm{gms}$. of protein per $\mathrm{kg}$. of body weight per 24 hours. These high values were obtained using as interval feeding through the day and at bedtime,
1 to 2 quarts of the Varco-type formula, 4 to which was added 2 ounces of Protenum. ${ }^{5}$ One and one-fourth quarts of this formula contained 120 gms. protein, 410 gms. carbohydrate and $36 \mathrm{gms}$. fat with a caloric value of 2444. The subjects were followed for from 32 to 64 days during which they approached or completely returned to a normal nutritional status.

While on this regimen it was found that the less severely malnourished subjects rapidly gained weight, and reported a feeling of well being with a marked increase in appetite. The more severely emaciated subjects tolerated the forced feedings less well and required a longer period of readjustment. If too vigorous therapy was attempted, gastrointestinal disturbances such as anorexia, vomiting or diarrhea occurred and the emaciated patient would actually lose more weight.

\section{RESULTS}

The changes in plasma volume and total circulating protein following the $1000 \mathrm{ml}$. intravenous saline infusion in the six normal subjects are presented in Table I. It will be seen that plasma

TABLE I

Changes in plasma volume and total circulating protein after saline infusion

Normal Subjects

\begin{tabular}{l|c|c|c|c|c|c}
\hline \hline & $\begin{array}{c}\text { Plasma volume } \\
\text { ml. }\end{array}$ & $\begin{array}{c}\text { Change in } \\
\text { plasma } \\
\text { volume } \\
\text { Pl. }\end{array}$ & $\begin{array}{c}\text { Total circulat- } \\
\text { ing protein } \\
\text { gms. }\end{array}$ & $\begin{array}{c}\text { Change in } \\
\text { total } \\
\text { circulating } \\
\text { protein } \\
\text { gms. }\end{array}$ \\
\cline { 2 - 7 } & Before & After & & Before & After & \\
\hline S. K. & 2580 & 3000 & +420 & 184.2 & 195.6 & +11.4 \\
I. T. & 2450 & 2927 & +477 & 181.7 & 194.2 & +12.5 \\
A. R. & 2710 & 3120 & +410 & 169.0 & 180.0 & +11.0 \\
L. H. & 3221 & 3878 & +657 & 225.5 & 244.1 & +18.6 \\
J. Ca & 2869 & 3240 & +371 & 177.1 & 188.5 & +11.4 \\
J. Ca & 2939 & 3239 & +300 & 174.8 & 189.6 & +14.8 \\
W. S. & 2409 & 2859 & +450 & 152.6 & 170.2 & +17.6 \\
\hline
\end{tabular}

volumes increased an average of $440.7 \mathrm{ml}$. The total circulating proteins, expressed in gms., following saline infusion were increased in every instance. The degree of this change, also expressed in gms., may be seen in the column to the far right of this chart and ranged from 11.0 to $18.6 \mathrm{gms}$. or an average of 13.9 gms.

Changes in plasma volume and total circulating protein following saline infusion in eight of the nine undernourished subjects are summarized in Table II. It will be seen that, in general, a lower de-

4 Varco-type formula: a high caloric, low fat mixture which consists of $1000 \mathrm{ml}$. skim milk, 4 ounces milk powder, six eggs, two egg whites and 300 gms. lactose.

${ }^{5}$ Kindly supplied by Dr. Warren Cox of the Mead Johnson and Company. 
TABLE II

Changes in plasma volume and total circulating protein after saline infusion

Undernourished Subjects

\begin{tabular}{l|c|c|c|c|c|c}
\hline \hline & $\begin{array}{c}\text { Plasma volume } \\
\text { ml. }\end{array}$ & $\begin{array}{c}\text { Change in } \\
\text { plasma } \\
\text { volume } \\
\text { Patients }\end{array}$ & $\begin{array}{l}\text { Total circulat- } \\
\text { ing protein } \\
\text { gms. }\end{array}$ & $\begin{array}{c}\text { Change in } \\
\text { total } \\
\text { circulating } \\
\text { protein } \\
\text { gms. }\end{array}$ \\
\cline { 2 - 5 } & Before & After & & Before & After & \\
\hline J. Ch & 2988 & 3355 & +367 & 244.8 & 218.1 & -26.7 \\
H. O. & 3564 & 3941 & +377 & 225.8 & 215.0 & -10.8 \\
J. H. & 3172 & 3236 & +64 & 213.9 & 165.9 & -48.0 \\
H. L. & 2050 & 1975 & -75 & 116.6 & 93.4 & -23.2 \\
E. G. & 3076 & 3455 & +379 & 227.6 & 223.8 & -3.8 \\
D. F. & 2873 & 2815 & -58 & 179.2 & 176.0 & -3.2 \\
L. M. & 2568 & 2730 & +162 & 176.4 & 174.5 & -1.9 \\
W. J. & 2446 & 2581 & +135 & 170.8 & 171.2 & +0.4 \\
\hline
\end{tabular}

gree of change in the plasma volumes occurred in these subjects as compared with the normal group; there being a decrease in two subjects and the maximum increase in the remaining six being $377 \mathrm{ml}$. The total circulating proteins decreased in all except one (W. J.) of the eight subjects. The amount of this change, expressed in gms., can be readily seen in the right hand column of this chart.

The initial plasma volumes recorded in the normal and undernourished subjects are listed in Table III as ml. (total volume), as $\mathrm{ml}$. per square meter of body surface and as ml. per $\mathrm{kg}$. of body weight. The range from 39.5 to $47.8 \mathrm{ml}$. per $\mathrm{kg}$. with a mean of $44.6 \pm 1.1 \mathrm{ml}$. per $\mathrm{kg}$. in the normal subjects is within normal limits. ${ }^{\circ}$ Initial

${ }^{6}$ Reported normal limits for plasma volume determined by the T-1824 dye method are: Gibson and Evans (12) $41.3 \mathrm{ml}$. per kg., Gregersen (16) $45 \mathrm{ml}$. per kg., Henschel et al. (17) $45.01 \pm 4.0 \mathrm{ml}$. per $\mathrm{kg}$.

TABLE III

Plasma volume in normal and undernourished subjects

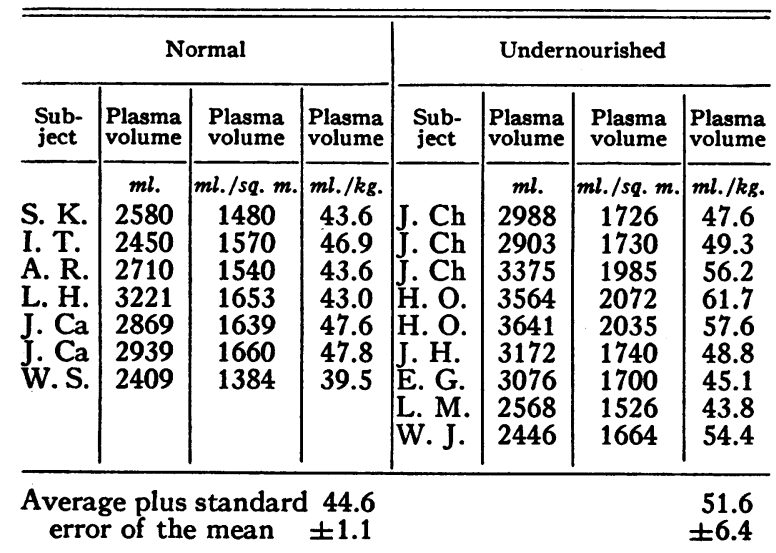

plasma volumes in the undernourished subjects ranged from 43.8 to $61.7 \mathrm{ml}$. per $\mathrm{kg}$. with a mean of $51.6 \pm 6.4 \mathrm{ml}$. per $\mathrm{kg}$. These values are similar to those reported by Henschel et al. (17) for subjects at the end of the first 12 weeks of their classical starvation studies.

Table IV shows the amount that albumin and globulin contributed to the change in total circulating protein. Albumin made up more of the increase in total circulating protein than did globulin in four of the normal subjects while in one the reverse was true. In five of the six undernourished subjects, however, albumin contributed more to the decrease in total circulating protein than did globulin. In either case the migration of protein is mainly due to the albumin fraction though the globulin portion also takes part to a smaller degree.

In Table $\mathrm{V}$ are summarized data on one subject (J. Ch.) who was studied through two different refeeding courses. This subject, a chronic alcoholic, first entered the hospital in severe undernutrition with marked liver damage and ascites. The initial observations were made at that time (Period I, day 1). It will be seen that following the saline infusion, the plasma volume increased by $367 \mathrm{ml}$. and the total circulating protein decreased by 26.7 gms. After 29 days on the high caloric diet the same studies were repeated (Day 29). During this time he had gained ten pounds in body weight with loss of ascites and edema. When the saline infusion test was repeated the plasma volume was found to increase by $348 \mathrm{ml}$; the total circulating protein did not change. The patient refused further hospitalization, left the institution and began to drink heavily and eat an inadequate diet. He re-entered the hospital 90 days later in severe undernutrition, manifesting ascites, dependent edema, marked dehydration and by roentgen examination, miliary and cavernous tuberculosis of the lung. The study using intravenous saline was performed immediately (Period II, day 1) and before any fluid and electrolyte disturbances were corrected. In this instance the plasma volume decreased $98 \mathrm{ml}$. and the total circulating protein decreased $18.4 \mathrm{gms}$. He was again started on the refeeding program in addition to streptomycin. During the succeeding 21 days he gained only 2 pounds in weight in spite of strict adherence to the refeeding program. Apart from hydration there was little clinical change in the subject. The 
TABLE IV

Change in total circulating protein, total circulating albumin and total circulating globulin

\begin{tabular}{|c|c|c|c|c|c|c|c|}
\hline \multicolumn{4}{|c|}{ Normal } & \multicolumn{4}{|c|}{ Undernourished } \\
\hline Patient & $\underset{\substack{\text { Total } \\
\text { proulating } \\
\text { protein }}}{\Delta}$ & $\underbrace{\triangle}_{\begin{array}{c}\text { Total } \\
\text { circulating } \\
\text { albumin }\end{array}}$ & $\underset{\substack{\text { Total } \\
\text { circulating } \\
\text { globulin }}}{\Delta}$ & Patient & $\underset{\substack{\text { circulating } \\
\text { protein }}}{\triangle}$ & $\underset{\substack{\text { Total } \\
\text { circulating } \\
\text { albumin }}}{\triangle}$ & $\underset{\substack{\text { Total } \\
\text { circulating } \\
\text { globulin }}}{\Delta}$ \\
\hline $\begin{array}{l}\text { S. K. } \\
\text { I. T. } \\
\text { A. R. } \\
\text { J. Ca } \\
\text { W. S. }\end{array}$ & $\begin{array}{l}\text { gms. } \\
+11.4 \\
+12.5 \\
+11.0 \\
+11.4 \\
+17.6\end{array}$ & $\begin{array}{r}\text { gms. } \\
+\quad 6.8 \\
+12.5 \\
+\quad 8.3 \\
+11.4 \\
+\quad 9.4\end{array}$ & $\begin{array}{r}\text { gms. } \\
+\quad 4.6 \\
+25.0 \\
+\quad 2.7 \\
0.0 \\
+\quad 8.2\end{array}$ & $\begin{array}{l}\text { H. O. } \\
\text { J. H. } \\
\text { H. L. } \\
\text { E. G. } \\
\text { D. F. } \\
\text { L. M. }\end{array}$ & $\begin{array}{l}\text { gms. } \\
-10.8 \\
-48.0 \\
-23.2 \\
-3.8 \\
-3.2 \\
-1.9\end{array}$ & $\begin{array}{c}\text { gms. } \\
+12.0 \\
-25.5 \\
-18.3 \\
-7.4 \\
-18.7 \\
-13.3\end{array}$ & $\begin{array}{c}\text { gms. } \\
-22.8 \\
-22.5 \\
-4.9 \\
+\quad 3.6 \\
+15.5 \\
+11.4\end{array}$ \\
\hline
\end{tabular}

tests were repeated (Day 21, period II) at which time the plasma volume was decreased, following saline infusion, by $30 \mathrm{ml}$. and the total circulating protein decreased by 27.8 gms. Just prior to discharge to a tuberculosis sanatorium the tests were again repeated (Day 64, period II). The subject had gained 14 pounds in weight with loss of ascites and edema and felt much improved; there had been no demonstrable change in the pulmonary tu- berculosis. It will be seen that the plasma volume was increased by $400 \mathrm{ml}$. and the total circulating protein was increased by 5.7 gms. The increase in total circulating protein after the saline infusion is interpreted as showing partial repletion of body tissue protein.

Data on three subjects in various degrees of undernutrition studied through the refeeding program are presented in Table VI. Subject H. O.

TABLE $V$

The influence of refeeding on the total circulating protein

\begin{tabular}{|c|c|c|c|c|c|c|c|c|c|c|c|}
\hline \multirow{2}{*}{ Date } & \multirow{2}{*}{ Weight } & \multicolumn{2}{|c|}{$\begin{array}{c}\text { Plasma volume } \\
\text { ml. }\end{array}$} & \multicolumn{2}{|c|}{$\begin{array}{c}\text { Total serum protein } \\
\text { gms. } \%\end{array}$} & \multicolumn{2}{|c|}{$\begin{array}{c}\text { Total circulating } \\
\text { protein } \\
\text { gms. }\end{array}$} & \multicolumn{2}{|c|}{$\begin{array}{c}\text { Serum albumin } \\
\text { gms. } \%\end{array}$} & \multicolumn{2}{|c|}{$\begin{array}{l}\text { Total circulating } \\
\text { albumin } \\
\text { gms. }\end{array}$} \\
\hline & & Before & After & Before & After & Before & After & Before & After & Before & After \\
\hline $\begin{array}{c}\text { Period I } \\
\text { Day } 1 \\
\text { Day } 29\end{array}$ & $\begin{array}{l}138 \\
148\end{array}$ & $\begin{array}{l}2988 \\
3652\end{array}$ & $\begin{array}{l}3355 \\
4000\end{array}$ & $\begin{array}{l}8.20 \\
7.31\end{array}$ & $\begin{array}{l}6.50 \\
6.68\end{array}$ & $\begin{array}{l}244.8 \\
267.1\end{array}$ & $\begin{array}{l}218.1 \\
267.1\end{array}$ & $\begin{array}{l}4.51 \\
4.67\end{array}$ & $\overline{3.86}$ & $\begin{array}{l}134.7 \\
170.6\end{array}$ & $\overline{154.4}$ \\
\hline $\begin{array}{l}\text { Period II } \\
\text { Day } 1 \\
\text { Day } 21 \\
\text { Day } 64\end{array}$ & $\begin{array}{l}130 \\
132 \\
144\end{array}$ & $\begin{array}{l}2903 \\
3375 \\
2855\end{array}$ & $\begin{array}{l}2805 \\
3345 \\
3255\end{array}$ & $\begin{array}{l}5.89 \\
8.09 \\
8.00\end{array}$ & $\begin{array}{l}5.45 \\
7.36 \\
7.18\end{array}$ & $\begin{array}{l}171.0 \\
273.0 \\
228.2\end{array}$ & $\begin{array}{l}152.6 \\
245.2 \\
233.9\end{array}$ & $\begin{array}{l}1.69 \\
2.33 \\
2.51\end{array}$ & $\begin{array}{l}1.57 \\
2.30 \\
2.41\end{array}$ & $\begin{array}{l}49.2 \\
78.6 \\
71.7\end{array}$ & $\begin{array}{l}44.0 \\
76.8 \\
78.4\end{array}$ \\
\hline
\end{tabular}

TABLE VI

The influence of refeeding on the total circulating protein

\begin{tabular}{|c|c|c|c|c|c|c|c|c|c|c|c|c|}
\hline \multirow{2}{*}{ Subject } & \multirow{2}{*}{ Date } & \multirow{2}{*}{ Weight } & \multicolumn{2}{|c|}{$\begin{array}{c}\text { Plasma volume } \\
m l .\end{array}$} & \multicolumn{2}{|c|}{$\begin{array}{c}\text { Total serum } \\
\text { protein } \\
\text { gms.\% }\end{array}$} & \multicolumn{2}{|c|}{$\begin{array}{c}\text { Total circulating } \\
\text { protein } \\
\text { gms. }\end{array}$} & \multicolumn{2}{|c|}{$\begin{array}{c}\text { Serum albumin } \\
\text { gms.\% }\end{array}$} & \multicolumn{2}{|c|}{$\begin{array}{l}\text { Total circulating } \\
\text { albumin } \\
\text { gms. }\end{array}$} \\
\hline & & & Before & After & Before & After & Before & After & Before & After & Before & After \\
\hline Н. 0. & $\begin{array}{l}\text { Day } 1 \\
\text { Day } 30 \\
\text { Day } 47\end{array}$ & $\begin{array}{l}127 \\
139 \\
145\end{array}$ & $\begin{array}{l}3564 \\
3641 \\
3310\end{array}$ & $\begin{array}{l}3941 \\
3880 \\
3460\end{array}$ & $\begin{array}{l}6.34 \\
7.00 \\
6.96\end{array}$ & $\begin{array}{l}5.46 \\
6.39 \\
7.00\end{array}$ & $\begin{array}{l}225.8 \\
254.8 \\
231.0\end{array}$ & $\begin{array}{l}215.0 \\
248.0 \\
242.0\end{array}$ & $\begin{array}{l}2.72 \\
3.31 \\
3.75\end{array}$ & $\begin{array}{l}2.77 \\
3.08 \\
3.71\end{array}$ & $\begin{array}{r}97.0 \\
120.5 \\
121.1\end{array}$ & $\begin{array}{l}109.0 \\
119.5 \\
128.4\end{array}$ \\
\hline J. Co & $\begin{array}{l}\text { Day } 1 \\
\text { Day } 52\end{array}$ & - & $\begin{array}{l}2588 \\
2575\end{array}$ & $\begin{array}{l}2816 \\
3380\end{array}$ & $\begin{array}{l}6.26 \\
6.60\end{array}$ & $\begin{array}{l}5.91 \\
6.30\end{array}$ & $\begin{array}{l}161.8 \\
171.5\end{array}$ & $\begin{array}{l}166.4 \\
213.0\end{array}$ & $\begin{array}{l}3.39 \\
3.85\end{array}$ & $\begin{array}{l}3.17 \\
3.47\end{array}$ & $\begin{array}{l}87.8 \\
99.2\end{array}$ & $\begin{array}{r}89.0 \\
117.3\end{array}$ \\
\hline J. H. & $\begin{array}{l}\text { Day } 1 \\
\text { Day } 34\end{array}$ & $\begin{array}{l}143 \\
158\end{array}$ & $\begin{array}{l}3172 \\
2522\end{array}$ & $\begin{array}{l}3236 \\
2679\end{array}$ & $\begin{array}{l}6.74 \\
6.64\end{array}$ & $\begin{array}{l}5.12 \\
6.53\end{array}$ & $\begin{array}{l}213.9 \\
167.5\end{array}$ & $\begin{array}{l}165.9 \\
174.9\end{array}$ & $\begin{array}{l}3.03 \\
4.16\end{array}$ & $\begin{array}{l}2.18 \\
4.03\end{array}$ & $\begin{array}{r}96.0 \\
105.0\end{array}$ & $\begin{array}{r}70.5 \\
109.5\end{array}$ \\
\hline
\end{tabular}


had a pulmonary abscess which responded sluggishly to penicillin and which evacuated spontaneously, after bronchoscopy, 25 days after the initial determinations. Tests on Day 1 showed an increase in plasma volume of $377 \mathrm{ml}$. after saline infusion and the total circulating protein decreased 10.8 gms. The same tests were repeated on Day 30 , during which time the subject had gained 12 pounds in weight, and showed an increase in plasma volume of $239 \mathrm{ml}$. and a decrease in total circulating protein of 6.8 gms. By Day 47 the subject had increased 18 pounds in weight and the tests revealed an increase in plasma volume of $150 \mathrm{ml}$. and an increase in total circulating protein of $11 \mathrm{gms}$; this increase in total circulating protein is interpreted as a normal response. Subject J. Co. was an aged patient with rheumatoid arthritis. The tests accomplished on Day 1 show that following the saline infusion, the plasma volume was increased by $228 \mathrm{ml}$. and the total circulating protein was increased by $4.6 \mathrm{gms}$. Fifty-two days later (Day 52) it will be seen the plasma volume increased $805 \mathrm{ml}$. and the total circulating protein increased $41.5 \mathrm{gms}$. following the infusion. This increase in total circulating protein is interpreted as a normal response and probably confirms the over-compensation phenomenon as demonstrated by Madden et al. (18) in protein repleted dogs. Subject J. H. had a severe pneumonia which responded only to combined penicillin and streptomycin therapy. The initial studies, Day 1, were accomplished nine days from the onset of illness and revealed an increase in plasma volume of $64 \mathrm{ml}$. and a decrease in total circulating protein of $48 \mathrm{gms}$. Repeat stucies on Day 34, after an increase of 15 pounds in weight, showed that, following the saline infusion, the plasma volume was increased by $157 \mathrm{ml}$. and the total circulating protein was increased by $7.4 \mathrm{gms}$.

\section{DISCUSSION}

The data presented in this report are best explained by the mechanism of protein exchange, or the dynamic equilibrium state, as presented by Whipple, Schoenheimer and others $(19,20)$.

It was noted, in Table I, that normal subjects responded to the saline infusion by increasing plasma volume, an average of $440.7 \mathrm{ml}$, and increasing total circulating protein, an average of 13.9 gms. The increase in plasma volume in these subjects is comparable to that obtained by Jacobson and Smyth (21) following intravenous saline infusions in normal subjects. The response to the saline infusion observed in the undernourished subjects, Table II, was characterized by an increase in plasma volume, an average of $169.6 \mathrm{ml}$, and a decrease in total circulating protein, an average of 14.7 gms. Although the increases in plasma volume demonstrated by the undernourished subjects were, generally, less than those increases shown by the normal subjects, more data of this type are needed to ascertain whether or not there is a correlation between change in total circulating protein and the amount of change in plasma volume. The changes in total circulating protein manifested by both groups of subjects were opposite in direction (i.e., increased $11 \mathrm{gms}$. or more in normal subjects and decreased in undernourished subjects). Since the degree of normality is generally more constant than is the degree of abnormality, in a given situation, it is not surprising that the total circulating protein in the normal subjects was increased within a rather narrow range $(+11$ to +18.6 gms.). The malnourished patients, however, were so far as could be determined clinically, in various degrees of undernutrition and it is presumed for that reason they showed a more variable response ( +0.4 to $-48.0 \mathrm{gms}$.).

These data show that under the influence of intravenous saline there is a migration of protein either into or out of the circulatory system. The direction of migration depends on the presence or absence of tissue protein stores. In the wellnourished individual where there are adequate protein stores the direction of flow is into the blood stream. On the other hand, where the protein stores are depleted as in the undernourished patient, proteins leave the circulation following the injection of saline. It may be that the liver cells are chiefly responsible for the different patterns demonstrated by the normal and abnormal subjects. These protein interchanges depend upon the passage of intact proteins through cellular membranes. This concept has already been suggested by Whipple (19).

It is an accepted fact that a normal serum protein concentration may mask an undernutritional state (22). Total circulating protein determinations, alone, may also convey an erroneous impression as to the subject's nutrition. We believe an 
intravenous saline infusion of at least $1000 \mathrm{ml}$. is a sufficient stimulus to either increase or decrease total circulating protein and so differentiate a normal state of protein nutrition, in the first instance, from a state of protein depletion in the second case.

\section{SUMMARY}

1. A relatively short and rapid method of demonstrating the presence or absence of labile protein stores in man is presented.

2. Plasma volume, total circulating proteins, and fractions (albumin and globulin) were determined before and after an intravenous infusion of 1 liter of physiological saline in six normal and in nine undernourished subjects.

3. The response to the saline infusion demonstrated by the normal subjects was characterized by an increase in plasma volume, an average of $440.7 \mathrm{ml}$. and an increase in total circulating protein, an average of 13.9 gms.

4. The response to the saline infusion demonstrated by the undernourished subjects was characterized by an increase in plasma volume, an average of $169.9 \mathrm{ml}$., and a decrease in total circulating protein, an average of $14.7 \mathrm{gms}$.

\section{BIBLIOGRAPHY}

1. Holman, R. L., Mahoney, E. B., and Whipple, G. H., Blood plasma proteins given by vein utilized in body metabolism; dynamic equilibrium between plasma and tissue proteins. J. Exper. Med., 1934, 59, 269.

2. Allison, J. B., Utilization of protein hydrolysates by normal and protein-depleted animals. Am. J. Med., 1948,5, 419.

3. Schoenheimer, R., The Dynamic State of Body Constituents. Harvard University Press, Cambridge, 1942.

4. Cannon, P. R., Some Pathologic Consequences of Protein and Amino Acid Deficiencies. Charles C. Thomas, Springfield, 1948.

5. Shearburn, E. W., The effect of saline infusions on blood volume and serum proteins of hypoproteinemic dogs. Proc. Soc. Exper. Biol. \& Med., 1942, 50, 140.

6. Calvin, D. B., Plasma protein changes follow:ng intravenous saline administrations. Am. J. Physiol., 1939, 126, 454.

7. Calvin, D. B., Changes in albumin and globulin ratios following intravenous saline injections. Am. J. Physiol., 1940, 129, 327.

8. Ravdin, I. S., Protein deficiency in surg:cal patients. Surg. Clin. North America, 1946, 26, 1305.

9. Localio, S. A., Chassin, J. L., and Hinton, J. W., Tissue protein depletion; a factor in wound disruption. Surg., Gynec. \& Obst., 1948, 86, 107.

10. Boothby, W. M., Sandiford, I., Sandiford, K., and Slosse, J., The effect of thyroxin on the respiratory and nitrogenous metabolism of normal and myxedematous subjects. Tr. A. Am. Physicians, 1925, 40, 195.

11. Deuel, J. H., Jr., Sandiford, I., Sandiford, K., and Boothby, W. M., A study of the nitrogen minimum: effect of 63 days of protein-free det on nitrogen partition products in urine and on heat production. J. Biol. Chem., 1928, 76, 391.

12. Gibson, J. G., 2nd., and Evans, W. A., Jr., Clinical studies of the blood volume. I. Clinical application of a method employing the azo dye "Evans Blue" and the spectrophotometer. J. Clin. Invest., 1937, 16, 301.

13. Gibson, J. G., 2nd, and Evelyn, K. A., Clinical studies of the blood volume. IV. Adaptation of the method to the photoelectric microcolorimeter. J. Clin. Invest., 1938, 17, 153.

14. Levey, S., A simple method of determining nonprotein nitrogen, total protein and albumin in blood serum samples bv using Conway cells. Am. J. Clin. Path., 1948, 18, 435.

15. Pillemer, L., and Hutchinson, M. C., Determination of albumin and globulin contents of human serum by methanol precipitation. J. Biol. Chem., 1945, 158, 299.

16. Gregersen, M. I., A practical method for the determination of blood volume with the dye T-1824. J. Lab. \& Clin. Med., 1944, 29, 1266.

17. Henschel, A., Michelsen, O., Taylor, H. L., and Keys, A., Plasma volume and thiocyanate space in famine edema and recovery. Am. J. Phys:ol., 1947, $150,170$.

18. Madden, S. C., George, W. E., Waraich, G. S., and Whipple, G. H., Blood plasma prose n regeneration as influenced by fasting, infection, and det factors: variable reserve stores of protein building material in dogs. J. Exper. Med., 1938, 67, 675.

19. Whipple, G. H., and Madden, S. C., Hemoglobin, plasma and cell prote. $n-$ the: $r$ interchanze and construction in emergencies. Med cine, 1944, 23, 215.

20. Schoenheimer, R., and Rittenberg, D., A study in the intermedary metabolism of animals with the aid of isotopes. Physiol. Rev., 1940, 20, 218.

21. Jacobson, S. D., and Smyth, C. J., Plasma volume changes following intravenous injection of pectin and physiological saline in man. Proc. Soc. Exper. Biol. \& Med., 1942, 50, 218.

22. Homburger, F., Problems in the evaluation of protein therapy. Am. J. Med., 1948, 5, 264. 